\title{
Femoral Fracture in Elderly: An Avoidable Cause?
}

\section{Cátia Regina Sartori ${ }^{1 *}$, CintiaLeci Rodrigues ${ }^{1}$, Jane de Eston Armond ${ }^{1}$, Rodrigo de Eston Armond ${ }^{1}$, Carlos Górios ${ }^{2}$, and Rodrigo Guilherme Varotti Pereira ${ }^{2}$}

${ }^{1}$ Department of Nursing and Health Sciences, University of Santo Amaro, São Paulo/SP, Brazil

${ }^{2}$ Department of Medicine, São Camilo University Center, São Paulo/SP, Brazil

*Corresponding author: Cintia Leci Rodrigues, Nursing Course Professor, Department of Nursing and Health Sciences, University of Santo Amaro, São Paulo/SP, Brazil, Georgia, Tel: +55 11 2141-8555; E-mail: kikarodrigues@hotmail.com

Rec Date: November 26, 2017, Acc Date: November 29, 2017, Pub Date: November 30, 2017

Citation: Sartori CG, Rodrigues C, Armond JE, Armond RE, Górios C, et al. (2017) Femoral Fracture in Elderly: An Avoidable Cause?. Med Case Rep Vol.4 No.1:54.

\section{Abstract}

Introduction: The frequency of femoral fractures has increased significantly in recent decades. It is known that this is closely related to geriatric population increase in our society, becoming a relevant public health problem.

Objective: To identify the epidemiological profile of femoral fractures after an accidental fall among elderly people living in the city of São Paulo.

Methods: This is a cross-sectional, quantitative, descriptive and retrospective study. We analyzed a total of 188 cases of fall among elderly (60 years old or more) diagnosed with femoral fractures, notified in The Information System for Violence and Accidents Surveillance (SIVVA), between January and October of 2017.

Results: The main injury diagnoses among elderly who suffered from fall accidents were femoral neck fracture $(28.7 \%)$ and pertrochanteric fracture $(24.5 \%)$. In relation to age and gender, femoral fractures due to accidental fall were predominantly among elderly with 80 years old or more $(51.1 \%)$ and females $(62.8 \%)$. Femoral fractures due to falls were more frequent in white individuals $(62.2 \%)$ main place of occurrence were in the elder residence and during daytime.

Conclusion: Femoral fractures among elderly occurred predominantly in female, white individuals, playing a major role due to their high morbimortality, making public health policies for elderly direct a greater attention to this population.

Keywords: Accidental falls; Aged; Femoral fractures; Health Information Systems (HIS)

\section{Introduction}

The ageing population is a phenomenon (multidimensional) which demands interdisciplinary confrontation. The increase number of the elderly population has been occurring very rapidly and progressively, especially in developing countries like Brazil [1].

One of the characteristics of the epidemiological profile of the elderly population is the prevalence of chronic diseases of gradual progression and high capacity to affect and reduce the autonomy and independence of the individual, due to this phase of life the use of health services in general is extended [2].

Studies about the elderly population have placed the fall and its consequences in evidence, since these have been a frequent cause of hospitalization, functional loss leading to enter a long-stay institution for the elderly, and increased morbimortality $[3,4]$.

The main risk factors for falls and fractures are age, gender, use of psychotropic drugs, alcohol abuse, tobacco, osteoporosis, early menopause, and physical inactivity, loss of balance, loss of cognitive capacity and presence of comorbidities. Among fractures, the most common are femoral fractures - now considered one of the greatest public health problems affecting mainly elderly women [5].

Therefore, it may cause loss of autonomy, functional limitation, dependence, disability, damage and death, especially in individuals over 65 years old. Studies show that the greater the agethe greater the risk of fall followed by fractures $[5,6]$.

The frequency of femoral fractures has increased significantly in recent decades. It is believed that this is closely related to the geriatric population increase in our society, since this disease occurs predominantly in elderly patients and progressive incidence with advancing age [5-7].

Considering the above, this study aimed to identify the main factors associated to falls with femoral fractures in elderly in the city of São Paulo, located in southeastern Brazil. 


\section{Methods}

This is a cross-sectional, quantitative, descriptive and retrospective study. We analyzed 188 cases of falls among elderly (60 years old or more) diagnosed with femoral fractures, notified in The Information System for Violence and Accidents Surveillance (SIVVA) of The Municipal Health Department of São Paulo, where notifications of accidents and violence are recorded by a notification form of suspected or confirmed cases, occurred in the city of São Paulo from January to October 2017.

Included in this study were elderly who suffered accident by accidental fall and diagnosed with femoral fracture. According to The International Disease Chapter (CID-10): S72.0 Femoral Neck Fracture, S72.1 Pertrochanteric Fracture, S72.2 Subtrochanteric Fracture, S72.3 Diaphysis Femoral Fracture, S72.4 Distal End Fracture of the Femur, S72.7 Multiple Fractures of the Femur, S72.8 Fracture of Other Parts of the Femur, S72.9 Femur Fracture Unspecified Part.

The variables used in this study were gender (male and female), age (years), race (white and black), education or scholarity (years of study), place of fall (home, public roads and long-term care home), time of fall (day and night), case evolution (hospital discharge, hospitalization and death). All variables were based on data from the public domain informed by the SIVVA (Information System for Violence and Accidents Surveillance) of The Municipal Health Department of São Paulo) of the Municipal Health Department of São Paulo [8].

The research project didn't require approval from the research Ethics Committee of The University, as it is about the use of secondary data of public domain database, according to resolution of The National Health Council (CNS) 466\12.

\section{Results}

During the study period (January - October 2017), there were 188 cases of accidental falls among elderly with a diagnosis of femoral fracture in the city of São Paulo.

As shown in Table $\mathbf{1}$ the main injury diagnoses among elderly who suffered fall accidents were Femoral Neck Fracture and Peritrochanteric Fracture.

Table 1 Injury diagnosis of elderly who suffered accidental fall in the city of São Paulo.

\begin{tabular}{|l|l|l|}
\hline Injury Diagnosis (CID 10) & N & f (\%) \\
\hline S72.0 Femoral Neck Fracture & 54 & 28.7 \\
\hline S72.1 Pertrochanteric Fracture & 46 & 3.2 \\
\hline S72.2 Subtrochanteric Fracture & 6 & 9 \\
\hline S72.3 Diaphysis Femoral Fracture & 17 & 2.1 \\
\hline S72.4 Distal End Fracture of the Femur & 4 & 0.5 \\
\hline S72.7 Multiple Fractures of the Femur & 1 & 7.4 \\
\hline S72.8 Fracture of Other Parts of the Femur & 14 & 24.5 \\
\hline S72.9 Femur Fracture Unspecified Part. & 46 & 100 \\
\hline Total & 188 \\
\hline
\end{tabular}

Regarding age and gender, femoral fractures due to accidental fall were predominantly among elderly with 80 years or more (51.1\%) and females $(62.8 \%)$.

Femoral fractures due to falls were more frequent in white individuals (62.2\%). According to data on scholarity, $23.4 \%$ of the elderly had less than 11 years of educational background.

Data for the location of fall: $19.1 \%$ happened at home, $1.6 \%$ in public road and other data were ignored. Regarding the time of fall: $5.9 \%$ during the day, $5.3 \%$ overnight and other data were ignored. Regarding the evolution of cases: hospitalization $(68.8 \%)$, death during care $(2.7 \%)$.

\section{Discussion}

Analyzing the secondary data obtained in the SIVVA revealed that 188 femoral fracture diagnoses occurred due to accidental fall. Regarding gender, a highest prevalence of elderly female population (62.8\%), in detriment to the male $(37.2 \%)$ found in this study being in line with other discoveries described in scientific literature [4]. When analyzing the results found there was a significant feminization of the elderly population, as well as the findings in similar Brazilian studies. The dynamics of elderly male and female population presents different rates of growth, markedly altered by different characteristics of morbimortality linked to gender $[2,4]$.

One of the most exposed bones to trauma in daily life, the largest and strongest bone in the human body, the femur has most of its fractures consolidated, and having a well vascularized muscular envelope [9]. The present study showed reported cases of accidents due to fall with diagnosis of femoral fractures, within the given period and locality in question. Unlike most of the studies performed, it took into account all occurrences registered by the Unified Health System (SUS), as well as any and all femoral fractures. 
Falls are the major cause of fractures among elderly, the population with osteoporosis and other chronic-degenerative diseases as an aggravating factor.

One limitation of this study was that it could not identify whether the elderly had osteoporosis or other chronic degenerative disease.

The predominance of females among those over 80 years old $(51.8 \%)$ can be explained by the loss of bone mass due to the reduction of estrogen in postmenopausal [9].

Fractures of the femoral neck have osteosynthesis as treatment option, partial or total hip arthroplasty, being the late mortality rate the same for any of the treatments $[10,11]$. The treatment is predominantly surgical, unless exceptionally in patients with comorbidities that contraindicate anesthesia, surgery or both $[10,11]$.

Studies have shown that common polypharmacy among elderly may be associated with a greater risk for falls: vasodilators, calcium channel blockers and benzodiazepines frequently used are related to falls [12].

Femoral fractures due to falls were more frequent in white individuals $(62.2 \%)$, due to the predisposition to develop osteoporosis $[6,12]$.

The low scholarity found in the present study contributed to social vulnerability, raising hypothesis that non-access to informationand lack of general knowledge can interfere in the maintenance of a healthy life. Learning opportunities can help people develop skillsand confidence in making adaptations in the aging process [6].

Epidemiology regarding the evaluation of occurrence of falls indicates the residence or surroundings as the main place of occurrence of falls, which coincides with the present study [13]. As for time of occurrence, there was a greater number of falls in the daytime period, which agrees with a study that presented similar results, inferring that this occurs due to the fact thatthe day corresponds to the period in which the elderly develop their activities of daily living, in relation to the night period $[13,14]$.

Trochanteric fractures are related to high rates of morbidity and mortality. The most prevalent and relevant clinical complications are deep venous thrombosis, pulmonary thromboembolism, superficial infection and deep infection, which may lead to death or permanent disability of the elderly [15].

The description that $2.7 \%$ of elderly died during care reveals the importance of new care models capable of improving the cost effectiveness of prevention, early detection and treatment of comorbidities associated with falls. Therefore, it is extremely important to know the profile of the elderly population that presented falls, with the purpose of equipping professionals to improve in care practices.

Even if we understand the complexity of the factors involved in the external causes of mortality, we must question the impact of government measures in face of the observed growth [16].
Prevention measures aimed at educating the elderly population about the risk of falls and how to avoid them should be introduced, taking into account that most falls occur at home during daily life activities [16]. It is important to emphasize that while some risk factors are intrinsic, such as muscle strength reduction and body balance deficit, others are extrinsic and can be easily eliminated or reduced, such as inadequate lighting and slippery or irregular flooring [17].

It must be considered that the medication of elderly is a prudent act which involves the knowledge of drug interactions and deleterious effects for this population of drugs that is commonly used in the adult population $[12,18,19]$.

\section{Conclusion and Final considerations}

Femoral fractures due to fall in elderly population living in the city of São Paulo were predominantly in females, elderly over 80 years old and of white skin. The most common fractures were of femoral neck and trochanteric. With this study it was verified that affects vulnerable and fragile elderly, who need specific care, but, above all, the need of preventive actions.

\section{References}

1. Dawalibi NW, Goulart RMM, Prearo LC (2014) Fatores relacionados à qualidade de vida de idosos em programas para a terceira idade. Ciênc Saúde Coletiva 19: 3505-3512.

2. Porciúncula RCR, Carvalho EF, Barreto KML, Leite VMM (2014) Perfil socioepidemiológico e autonomia de longevos em Recife$P E$, nordeste do Brasil. Rev bras geriatr gerontol 17: 315-325.

3. Antes DL, Schneider IJC, d'Orsi E (2015) Mortalidade por queda em idosos: estudo de série temporal. Rev Bras Geriatr Gerontol 18: 769-778.

4. Kuznier TP, Souza CC, Chianca TCM, Ercole FF, Alves M (2015) Fatores de risco para quedas descrito na Taxonomia da NANDA-I para uma população de idosos. R Enferm Cent $O$ Min 5: 1855-1870.

5. Soares DS, Mello LM, Silva AS, Nunes AA (2015) Análise dos fatores associados a quedas com fratura de fêmur em idosos: um estudo caso-controle. Rev bras Geriatr Gerontol 18: 239-248.

6. Santana DF, Reis HFC, Ezequiel DJS, Ferraz DD (2015) Perfil funcional, sociodemográfico e epidemiológico de idosos hospitalizados por fratura proximal de fêmur. Rev Kairós 18: 217-234.

7. Astur DC, Arliani GG, Balbachevsky D, Fernandes HJA, Reis FB (2011) Fraturas da extremidade proximal do fêmur tratadas no Hospital São Paulo/Unifesp - estudo epidemiológico. RevBras Med 68.

8. http://www.prefeitura.sp.gov.br

9. Conceição AM, Garcia Filho FC, Dias JP (2016) Internações por fraturas de fêmur em Salvador, Bahia. Rev. baiana saúde pública 40: 298-314.

10. Ravikumar KJ, Marsh G (2000) Internal fixation versus hemiarthroplasty versus total hip arthroplasty for displaced subcapital fractures of femur-13 year results of a prospective randomised study. Injury 31: 793-797. 
11. Takano MI, Moares RCP, Almeida LGMP, Queiroz RD (2014) Análise do emprego do parafuso antirrotacional nos dispositivos cefalomedulares nas fraturas do fêmur proximal. Rev Bras Ortop 49: $17-24$

12. Coutinho ESF, Silva SD (2002) Uso de medicamentos como fator de risco para fratura grave decorrente de queda em idosos Cad. Saúde pública 18: 1359-1366.

13. Vieira CPB, Rocha ACS, Carvalho GMA, Sales JCS, Luz MHBA, et al. (2016) Fatores de risco associados a quedas em idosos. Revenferm UFPE 10: 4028-4035.

14. Fhon JRS, Rodrigues RAP, Neira WF, Huayta VMR, Robazzi MLCC (2016) Fall and its association with the frailty syndrome in the elderly: systematic review with meta-analysis. Rev Esc Enferm USP 50: 1003-1010.

15. Borger RA, Leite FA, Araújo RP, Pereira TFN, Queiroz RD (2011) Avaliação prospectiva da evolução clínica, radiográfica e funcional do tratamento das fraturas trocantéricas instáveis do fêmur com haste cefalomedular. Rev bras Ortop 46: 380-389.

16. Rosa TSM, Moraes AB, Peripolli A, Santos Filha VAV (2015) Perfil epidemiológico de idosos que foram a óbito por queda no Rio Grande do Sul. Rev Bras Geriatr Gerontol 18: 59-69.

17. Oliveira DMN, Rocha AG, Costa MML, Nascimento SM (2016) Dificuldades enfrentadas por enfermeiros na assistência prestada ao idoso acometido por fratura de fêmur. Revenferm UFPE 10: 4862-4869.

18. Taguchi CK, Santos TFO, Nascimento RS, Silva AR, Raposo OFF, et al. (2016) Efectividaddel programa de prevención de caídas enancianos. Distúrbios Comun 28: 286-294.

19. http://www.projetodiretrizes.org.br 